\title{
IMPLEMENTASI MANAJEMEN KELAS DAN RELEVANSINYA DENGAN HASIL BELAJAR SISWA DI MADRASAH IBTIDAIYAH QURANIAH 8 PALEMBANG
}

Ibrahim, Nita Nur Cahyani, Mardiah Astuti, Febriyanti

\author{
Universitas Islam Negeri Raden Fatah Palembang
}

Jl. Prof. K. H. Zainal Abidin Fikri Km. 3.5, Palembang, Sumatera Selatan

e-mail: ibrahim_uin@ radenfatah.ac.id.,nitanurcahyani91@gmail.com, mardiah_uin@ radenfatah.ac.id. febriyanti_uin@radenfatah.ac.id.

Abstrak: Penelitian ini bertujuan untuk menganalisis implementasi manajemen kelas dan relevansinya terhadap peningkatan hasil belajar, dengan fokus kajian pada dua hal yakni: (1) implementasi manajemen kelas, (2) faktor pendukung dan penghambat implementasi manajemen kelas. Penelitian ini dilaksanakan di madrasah Ibtidaiyah Quraniah 8 Palembang, dengan menggunakan metode penelitian kualitatif berbasis studi deskriptif. Dalam penelitian ini yang menjadi informan adalah kepala sekolah, Guru walikelas dan staff tata usaha. Data diperoleh dengan teknik observasi, wawancara dan dokumentasi. Teknik analisis data melalui reduksi data, penyajian data, dan penarikan kesimpulan, keabsahan data dalam penelitian ini menggunakan keabsahan data dengan triangulasi. Hasil penelitian ini menunjukan bahwa implementasi manajemen kelas di MI Quraniah 8 Palembang sudah berjalan dengan baik namun kurang maksimal. Impementasi tersebut terwujud dalam pengaturan fasilitas yang terdiri dari pengaturan ruang belajar, pengaturan tempat duduk, pengaturan ventilasi udara, pengaturan cahaya. Selain itu pengaturan alat pembelajaran dan pengaturan suasana pembelajaran. Faktor penghambatnya di antaranya kurangnya kesadaran peserta didik dalam memenuhi hak dan tanggung jawab dalam menjalankan tugasnya. Kemudian kurang memadainya fasilitas, gedung dan sarana kelas. Sedangkan, faktor pendukungnya yaitu guru yang aktif dan kreatif dalam mengarahkan perkembangan anak didiknya. Pengelolaan kelas berhubungan dengan peningkatan hasil belajar siswa, semakin nyaman siswa belajar, maka akan semakin baik hasil belajar siswa.

Kata Kunci: Manajemen Kelas, Hasil belajar, Suasana Pembelajaran

\begin{abstract}
This study aims to analyze the implementation of classroom management and its relevance to improving learning outcomes, with the focus of the study on two things: (1) classroom management implementation, (2) supporting and inhibiting factors for classroom management implementation. This research was conducted at Madrasah Ibtidaiyah Quraniah 8 Palembang, using qualitative research methods based on descriptive studies. In this study, the informants were the principal, homeroom teacher and administrative staff. The data were obtained by using observation, interview and documentation techniques. The data analysis technique is through data reduction, data presentation, and drawing conclusions, the validity of the data in this study uses the validity of the data by triangulation. The results of this study indicate that the implementation of classroom management at MI Quraniah 8 Palembang has been going well but not optimally. This implementation is manifested in the arrangement of facilities consisting of the arrangement of the study room, the arrangement of the seats, the arrangement of the air ventilation, the arrangement of the light. In addition, setting learning tools
\end{abstract}


and setting the learning atmosphere. The inhibiting factors include the lack of awareness of students in fulfilling their rights and responsibilities in carrying out their duties. Then inadequate facilities, buildings and classroom facilities. Meanwhile, the supporting factors are teachers who are active and creative in directing the development of their students. Classroom management is related to improving student learning outcomes, the more comfortable students learn, the better student learning outcomes.

Keywords: Class Management, Learning Outcomes, Learning Atmosphere

\section{PENDAHULUAN}

Pengembangan ilmu pengetahuan dan teknologi telah membawa perubahan di semua aspek pada kehidupan manusia yang mana berbagai permasalahan hanya dapat dipecahkan dengan upaya penguasaan serta peningkatan ilmu pengetahuan dan teknologi. (Huda, 2015). Agar mampu berperan dalam persaingan global, maka bangsa kita perlu terus mengembangkan dan meningkatkan kualitas sumber daya manusianya. Jadi, peningkatan kualitas sumber daya manusia merupakan kenyataan yang harus dilakukan secara terencana, terarah, intensif, efektif dan efisien dalam proses pembangunan. (Bani, 2016).

Peningkatan kualitas sumber daya manusia salah satu caranya ditempuh lewat pendidikan. Pendidikan dapat meningkatka kualitas sumber daya manusia, sebab pendidikan memberikan bekal kompetensi dan keterampilan. (Almasri, 2017). Dalam dunia pendidikan guru sangat berperan dalam membantu perkembangan siswa untuk mencapai tujuan hidupnya secara optimal. (Wajdi, 2021). Adapun kegiatan yang dilaksanakan guru secara umum di dalam kelas terdiri dari dua yakni kegiatan mengajar, dan kegiatan mengelola kelas. Adapun indikator pendukung kegiatan mengelola kelas untuk menciptakan kondisi yang efektif dalam proses belajar-mengajar adalah penyusunan dan pengaturan ruang belajar hendaknya memungkinkan anak duduk berkelompok dan memudahkan guru bergerak secara kuasa untuk membantu siswa dalam belajar. (Faruqi, 2018). Selanjutnya pengaturan kondisi ruangan kelas meliputi ventilasi dan tata cahaya, pemeliharaan kebersihan dan penataan keindahan ruang kelas. Pengaturan tempat duduk siswa dan yang terakhir adalah pengaturan lingkungan fisik kelas. (Sumar, 2020).

Berdasarkan observasi awal wawancara dengan kepala sekolah MI Quraniah 8 Palembang peneliti menemukan permasalahan pokok dalam penelitian ini yaitu kurang memadainya fasilitas perlatan belajar di dalam kelas, rasio siswa yang tidak sesuai dengan ukuran ruangan, penataan tempat duduk siswa yang tidak maksimal. Kurangnya kapasitas ruangan kelas dengan jumlah siswa membuat siswa dan guru tidak memiliki ruang gerak yang luas untuk bereksplorasi saat pembelajaran berlangsung. Tidak hanya itu kurangnya peralata dan perabotan di dalam kelas menjadikan penyimpanan barang-barang masih kurang baik. Permasalahan lain yakni proses pembelajaran yang menggunakan dua kurikulum yaitu KTSP dan K13 karena terbatasnya fasilitas dan pemahaman guru sehingga untuk K13 hanya diterapkan pada 
siswa kelas 5 dan 6 saja. Kondisi ini tentu menggangu kenyamanan guru saat mengajar, yang akhirnya berdampak pada kenyamanan siswa. Permasalahan lain, kurangnya media dan alat-alat pembelajaran seperti gambar atau alat-alat peraga yang dapat membantu proses pembelajaran berlangsung.

Kodisi permasalahan di atas tentu jika tidak diatasi akan dapat mengganggu proses pembelajaran, dan pencapaian tujuan pembelajaran sebagaimana yang diharapkan. Sebagaimana yang dikatakan oleh para ahli bahwa sebenarnya pembelajaran merupakan proses mengelola lingkungan belajar (termasuk kelas) agar siswa dapat dengan mudah terfasilitasi untuk belajar. Oleh karena itu lah pengelolaan kelas sangat penting untuk dilakukan guru sebelum dan saat pembelajaran sedang berlangsung.

Manajemen kelas terdiri atas dua kata, yaitu manajemen dan kelas. Manajemen kelas merupakan keterampilan pengajar untuk membentuk iklim pembelajaran yang kondusif dan mengendalikannya jika terjadi gangguan dalam pembelajaran. (Erwinsyah, 2017). Manajemen kelas dapat diartikan sebagai kemampuan guru dalam mendayagunakan potensi kelas berupa pemberian kesempatan yang seluas-luasnya pada setiap individu untuk melakukan kegiatan yang kreatif dan terarah. (Asmara \& Nindianti, 2019). Jadi, disimpulkan bahwa manajemen kelas adalah usaha sadar untuk merencanakan, mengorganisasikan, mengaktualisasikan, dan melaksanakan pengawasan atau supervisi terhadap program dan kegiatan yang ada di kelas sehingga proses belajar mengajar dapat berlangsung secara sistematis, efektif, dan efisien.
Dengan demikian, segala potensi peserta didik mampu dioptimalkan. Dalam kegiatan pengelolaan kelas terdapat beberapa unsur yang mempengaruhi pengelolaan kelas di antaranya: a) pengaturan tempat belajar tempat belajar seperti ruang kelas dan ruangan yang lainnya seperti laboraturium, workshop/bengkel kerja, dan sebagainya; b) pengaturan siswa; c) pemilihan bentuk kegiatan; d) pemilihan media pembelajaran; e) penilaian. (Firdaus, 2016).

Beberapa indikator dari manajemen kelas itu sendiri yaitu: a) ruangan tempat berlangsungnya proses belajar-mengajar; b) pengaturan tempat duduk; c) ventilasi dan pengaturan cahaya; d) peraturan alat-alat pengajaran.Beberapa faktor pada manajemen kelas antara lain sebagai berikut: a) faktor dinamika kelas; b) faktor kurikulum; c) faktor gedung dan sarana kelas; d) faktor tenaga kependidikan; e) faktor siswa; f) fasilitas. (Sa'diyah, 2017). Terdapat beberapa faktor yang harus diperhatikan oleh guru untuk menumbuhkan sikap murid seperti di atas karena berpengaruh dalam pengelolaan siswa sebagai anggota kelas. Secara umum faktor tersebut digolongkan menjadi dua yaitu faktor internal dan faktor eksternal. Faktor internal peserta didik berkaitan dengan masalah emosi pikiran serta perilaku kepribadian siswa yang unik menyebabkan siswa berbeda dari berbagai aspek yaitu perbedaan biologis, intelektual, dan psikologis. Sedangkan faktor ekternal siswa terkait dengan pengelolaan suasana lingkungan belajar, penempatan siswa, pengelompokan kelas dan jumlah siswa di kelas.(Aulia \& Sontani, 2018). Jadi, dapat 
Hikmah, Vol. 18, No. 2, Juli-Desember 2021， p-ISSN: 1829-8419 e-ISSN: 2720-9040

disimpulkan bahwa terjadinya kenyamanan di dalam kelas disebabkan oleh dua faktor yaitu faktor intern dan ekstern siswa. usaha untuk mengatasi terjadinya kekacauan di kelas dibutuhkan adanya suatu usaha dari guru dalam rangka meminimalisir gangguan kenyamanan dalam manajemen kelas. (Arianti, 2019).

Setiap guru tentu memiliki cara yang berbeda-beda dalam mengelola kelas, hal itu didasarkan pada beberapa hal seperti kondisi kelas, kondisi sarana dan prasarana, gaya belajar siswa, karakteristik dan kemampuan siswa, tujuan dan capaian pembelajaran. (Anwar et al., 2020). Guru pada Madrasah Ibtidaiyah Quraniah 8 Palembang memiliki keunikan tersendiri dalam mengelola kelas. Namun untuk melihat keunikan tersebut terlebih dahulu dilakukan Grand Tour terhadap penelitian sejenis untuk melihat perbedaan sekaligus mengklaim keunikan penelitian ini dengan penelitian lain.

Hasil Grand Tour menunjukkan beberapa penelitian yang relevan yakni (1) Penelitian tentang strategi pengelolaan kelas yang kondusif dan menyenangkan di MI. penelitian ini fokus pada pengaturan psikologi anak untuk perwujudan pengelolaan kelas tersebut. (Gafur \& Mustafida, 2019). (2) Penelitian tentang peran guru dalam pengelolaan kelas, yang fokus kajiannya pada kompetensi pedagogi guru dalam mengelola kelas. (Mutiaramses et al., 2021). (3) Pengelolan kelas dalam pembelajarn kidah Akhlak pada masa pandemic Covid-19. Fokus kajian pada penyesuaian kondisi pandemi dengan pengelolaan kelas berbasis Virtual. (Fauziyah, 2021). Penelitian tentang pengelolaan kelas berbasis pembelajaran tematik. Fokus kajian pada pendekatan tematik yang diterapkan pada tingkat sekolah dasar. (Nurmala, 2019). Penelitian tentang pengaruh pengelolaan kelas terhadap hasil belajar siswa MI, yang mana fokusnya menguji model pegelolaan kelas terhadap peningkatan hasil belajar siswa. (Rosidah, 2020). Strategi pengelolaan kelas di tingkat MI, dengan fokus kajian pada analisis terhadap straegi yang telah ditetapkan dalam mengelola kelas. (Isnanto et al., 2020).

Dari beberapa penelitian tersebut tampak distingsi dengan penelitian ini, dimana penelitian ini berfokus pada manajemen pengelolaan kelas dengan mempertimbangkan minat belajar siswa sebagai dasar pengelolaan. Selain itu di tengah keterbatasan sarana dan prasarana, guru tetap berupaya meningkatkan kreativitasnya dalam pegelolaan kelas. Penelitian ini juga berfokus pada proses implementasi sekaligus pada relevansinya dengan hasil belajar.

Penelitian diharapkan dapat direkomendasikan kepada guru MI dalam mengelola kelas yang dapat meningkatkan minat belajar dan hasil belajar siswa. Penelitian ini juga direkomendasikan kepada kepala sekolah dalam memanajemen kelas sehingga pembelajaran dapat berjalan sebagaimana yang diharapkan, dan mencapai tujuan pembelajaran.

Berdasarkan uraia masalah yang telah dipaparkan di atas, maka diidentifikasikan manajemen kelas pengaturan tata ruang ruang kelas sangat erat kaitannya dengan proses dan hasil pembelajaran di sekolah. Hal ini yang menjadi sebab ketertarikan 
penulis untuk melakukan penelitian lebih lanjut dan mengambil judul Implementasi Manajemen Kelas Di MI Quraniah 8 Palembang. Penelitian ini bertujuan untuk menaganalisis: (1) implementasi manajemen kelas di MI Quraniah 8 Palembang, (2) penghambat dan pendukung dalam pelaksanaan implementasi manajemen kelas di MI Quraniah 8 Palembang.

\section{METODE PENELITIAN}

Penelitian ini menggunakan pendekatan kualitatif untuk mendeskripsikan permasalahan dan fokus penelitian. Hal tersebut sesuai yang di ungkapkan oleh Lexy J. Moleong bahwa data yang dikumpulkan dalam penelitian kualitatif adalah berupa kata-kata, gambar dan bukan angka-angka. (Moloeng, 2018). Penelitian ini dilaksanakan di MI Quraniah 8 Palembang. Subjek dalam penelitian ini adalah orang yg diwawancarai atau diminta informasi oleh peneliti, yang menjadi informan dalam penelitian ini ialah kepala sekolah, wali kelas, dan staff tata usaha serta dokumen-dokumen yang ada.

Teknik pengumpulan data langkah yang paling strategis dalam penelitian, teknik yang penulis gunakan pada penelitian ini adalah teknik observasi, teknik wawancara serta dokumentasi. Teknik analisis data yang digunakan pada penelitian ini sebagaimana yang dijelaskan oleh Miles and Huberman yang melalui langkah-langkah sebagai berikut reduksi data, penyajian data (data display), dan verification data/menarik kesimpulan. Pelaksanaan teknik pemeriksaan didasarkan atas sejumlah kriteria tertentu. Ada empat kriteria yang digunakan, yaitu derajat kepercayaan (credibility), keteralian (transferability), kebergantungan (depenbality), dan kepastian (comfirmability). (Sugiyono, 2013, p. 270) Uji keabsahan data pada penelitian ini menggunakan uji kredibilitas. Uji kredibilitas data atau kepercayaan terhadap data hasil penelitian yang dilakukan dengan menggunakan teknik triangulasi.

\section{HASIL DAN PEMBAHASAN}

Sebagaimana yang telah disebutkan pada bagian pendahuluan bahwa pembahasan penelitian ini sesuai dengan tujuan penelitian yakni untuk menganalisis implementasi manajmen kelas dan faktor pendukung dan penghambat manajemen kelas di MI Quraniah 8 Palembang.

\section{Implementasi Manajemen Kelas dalam Proses Belajar Mengajar}

Suatu pembelajaran dapat dikatakan efektif, apabila terjadi interaksi yang baik antara guru dengan siswa dan bertujuan untuk mencapai suatu tujuan belajar tertentu dengan cara memfasilitasi pengetahuan dan keterampilan peserta didik melalui kegiatan /aktivitas yang dapat membantu serta memudahkan siswa dalam belajar. Untuk membangun suasana yang harmonis, dan komunikatif, tugas guru adalah meningkatkan prestasi belajar serta senantiasa memberikan bimbingan dan pengarahan pada siswa. Salah satu faktor utama keberhasilan manajemen kelas juga adalah dilihat dari bagaimana seorang guru mengelola kelasnya ketika proses pembelajaran berlangsung. Hal ini juga di sampaikan oleh bapak Hendri Susanto selaku wali kelas di MI Quraniah 8 Palembang. Ketika diwawancara beliau mengatakan: 
"Jadi menurut bapak pribadi pengelolaan kelas sangatlah penting bagi guru, karena faktor penentu dari keberhasilan belajar salah satunya adalah cara bagaimana guru itu sendiri pintar mengelola kelas. Dan saya biasanya terlebih dahulu melihat kondisi siswa didalam kelas apa sudah kondusif atau belum."

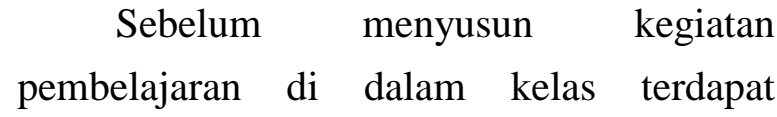
pelaksanaan manajemen kelas yang efektif. Lingkungan fisik tempat belajar dalam pengelolaan kelas mempunyai pengaruh penting terhadap hasil pembelajaran. Lingkungan fisik yang menguntungkan dan memenuhi syarat minimal mendukung meningkatnya intensitas proses pembelajaran dan mempunyai pengaruh positif terhadap pencapaian tujuan pembelajaran. Lingkungan fisik yang dimaksud meliputi: a) Ruangan tempat berlangsungnya proses belajar-mengajar: menurut pendapat Suhaenah Suparno, mengemukakan kriteria yang harus dipenuhi ketika melakukan penataan ruang kelas adalah menunjang efektifitas proses belajar, bersifat fleksibel, adanya fasilitas yang mendukung, dan mampu membantu siswa meningkatkan motivasi belajarnya. Berdasarkan hasil observasi, ruang kelas di MI Quraniah 8 Palembang sudah cukup memadai dengan jumlah siswa yang maksimal 28 siswa tetapi jika dilihat dari standar akreditasi pemerintah belum cukup sesuai dengan ukuran nya. Selain melakukan wawancara dengan wali kelas, peneliti juga melakukan wawancara kepada ibu Hotipa selaku wali kelas terkait tentang ruangan belajar pada proses pembelajaran, beliau mengatakan bahwa :
"Menurut saya untuk ukuran kelas di MI Quraniah 8 Palembang sudah sesuai tetapi kalau menurut standar akreditasi masih belum sesuai dengan ukurannya. Sama hal nya seperti yang dikatakan oleh ibu siti sarah untuk mengenai ukuran di kelas sudah sesuai akan tetapi jika dilihat berdasarkan standar akreditasi pemerintah belum cukup sesuai dalam menunjang pendidikan"

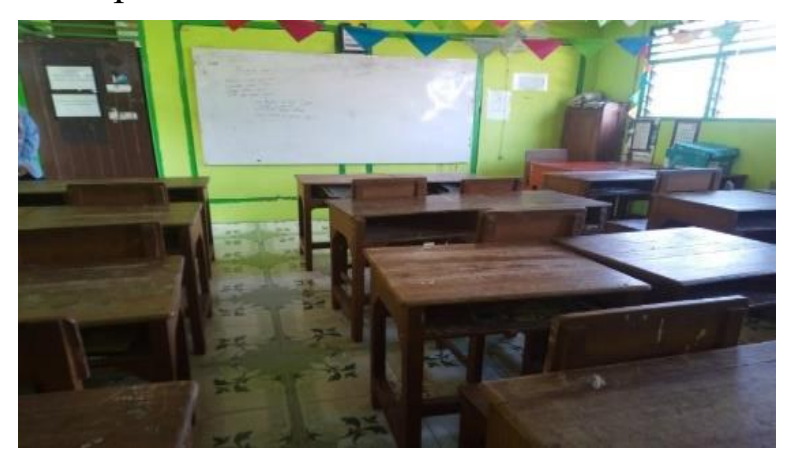

Gambar 1. Kondisi Ruang kelas MI Quraniah 8 Palembang

Berdasarkan hasil observasi, wawancara, dan dokumentasi dapat dipahami ukuran ruang kelas di MI Quraniah 8 Palembang sudah sesuai, untuk ukuran dengan jumlah siswa maksimal 28 orang dan sangat memungkinkah siswa bergerak dan tidak berdesak-desakan dan memudahkan siswa untuk melakukan aktifitas belajar. Jika dilihat menurut standar akreditasi belum sesuai dengan ukuran yang telah ditentukan, diikarenakan lokasi tempat yang tidak memadai. Lalu untuk kenyamanan belajar siswa dapat dipahami dari hasil penelitian di atas bahwa sebelum para siswa belajar yang pertama harus diperhatikan yaitu kebersihan kelas yang selalu terjaga seperti pada gambar di atas. b) Pengaturan tempat duduk Dalam mengatur tempat duduk yang penting adalah memungkinkan terjadinya tatap muka dengan demikian guru dapat mengontrol tingkah laku siswa. Hasil wawancara dengan tenaga pendidik tersebut diperkuat dengan 
hasil observasi yang penulis lakukan, bahwasanya pengaturan tempat duduk untuk saat ini dikarenakan pandemi jadi setiap siswa duduk satu bangku satu orang dan berjarak, tetapi jika tidak dalam kondisi pandemi bisa satu bangku dua orang. Untuk pengaturan tempat duduk jika tidak dalam kondisi pandemi setiap 3 bulan sekali ada perubahan dalam pengaturan tempat duduk. Adapun Hasil wawancara peneliti mengenai pengaturan tempat duduk Menurut pernyataan yang dikemukakan Ibu Rohima :

"pada penempatan tempat duduk cara tergantung dengan guru-guru yang ingin anak-anaknya belajar seperti bentuk pola melingkar dan yang seperti biasa dan ada juga guru yang mejanya digabung menjadi satu (pola diskusi). Tetapi, lebih sering duduk seperti biasa."

Pernyataan di atas juga didukung oleh informasi bapak Hendri Susanto selaku wali kelas, sebagai berikut :

"untuk pola penempatan peserta didik tidak beruba-ubah, tetapi tergantung pada guru yang mengajar yang sesuai dengan kebutuhan yang di pakai misalnya, apabila ada sebuah diskusi maka meja akan di bentuk perkelompok baik bentuk melingkar (model O) atau model U"

Penataan ruang dan fasilitas yang ada di kelas harus mampu membantu siswa meningkatkan motivasi siswa untuk belajar sehingga mereka merasa senang belajar. Indikator ini tentu tidak dengan segera diketahui, tetapi guru yang berpengalaman akan dapat melihat apakah siswa belajar dengan senang atau tidak. Dapat Penulis simpulkan dari hasil observasi, wawancara, dan dokumentasi bahwa dalam pengaturan tempat duduk di MI Quraniah 8 Palembang sudah dilakukan dengan baik, hal ini didasarkan pada hasil wawancara, observasi, dokumentasi serta teori yang penulis gunakan. Dalam setiap kelas di MI Quraniah 8 Palembang, tempat duduk tersusun dengan rapi yang menggunakan tipe-tipe letak duduk yang beragam untuk mendukung kenyamana peserta didik dalam belajar. c) Ventilasi dan Pengaturan Cahaya: adalah aset penting untuk terciptanya suasana belajar yang nyaman. oleh karena itu harus cukup cahaya dan sirkulasi udara harus cukup menjamin kesehatan siswa. (Afriza, 2014, p. 25) Dari hasil observasi suhu, ventilasi dan penerangan di MI Quraniah 8 Palembang sudah cukup bagus dan terang ada 4 jendela yang menggunakan kaca tako kalaupun ketika sedang dalam cuaca mendung bisa menggunakan lampu kelas agar pembelajaran tetap berjalan. Untuk suhu ruangan tidaklah panas karena setiap kelas dilengkapi dengan dua kipas angin. Berikut hasil wawancara dengan Ibu Rohima selaku Wali kelas dan Waka Kesiswaan, sebagai berikut :

"suhu, ventilasi dan penerangan adalah aset penting untuk terciptanya suasana belajar mengajar yang nyaman. Oleh karena itu, ventilasi harus cukup menjamin kesehatan siswa, dan ventilasi sudah diatur sejak pembangunan sekolah hanya saja kita harus membersihkan ventilasi setiap saat agar udara yang masuk terasa segar tidak ada debu."

Berikut hasil wawancara dengan ibu Hotipah selaku Kepala Sekolah, sebagai berikut :

"untuk pengaturan cahaya sendiri, jika dalam ruang kelas terasa kurang terang saat proses belajar mengajar berlangsung maka sebaiknya lampu dinyalakan supaya terang. Sehingga peserta didik dapat melihat dengan 
jelas materi yang ditulis di papan tulis ataupun tidak mengganggu penglihatan sehingga menurunkan konsentrasi belajar mengajar".

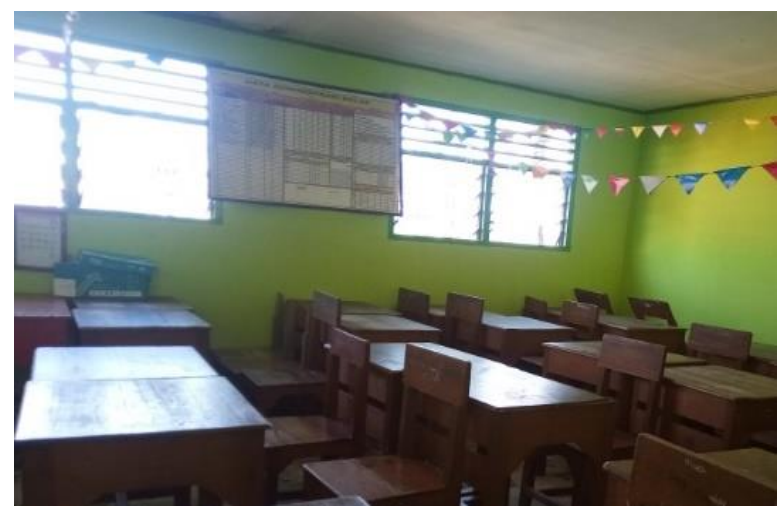

Gambar 2. Ventilasi dan pencahayaan kelas

Berdasarkan hasil observasi, wawancara, dan dokumentasi diatas setiap ruangan memiliki pendingin ruangan seperti kipas angin agar udara stabil didalam ruangan. Sehingga peserta didik dapat melihat dengan jelas materi yang ditulis di papan tulis ataupun tidak menggangu pengelihatan sehingga menurunkan konsentrasi belajar megajar karena suhu, ventilasi dan penerangan adalah asset penting untuk menciptakan suasana belajar yang nyaman dan kondusif. Ventilasi dan pengaturan cahaya di MI Quraniah 8 Palembang sudah cukup baik. Hal ini dilihat dari pengaturan cahaya yang ada di dalam kelas, pada gambar di bawah terlihat bahwa cahaya yang masuk melalui ventilasi ruang kelas mampu menerangi kelas tanpa adanya alat penerangan lain yang mendukung seperti lampu. d) Pengaturan alat-alat pengajaran; Di antara alat-alat pengajaran di kelas yang harus diatur adalah Perpustakaan Kelas, Sekolah yang maju ada perpustakaan di setiap kelas, Pengaturannya bersama-sama siswa. Alat peraga atau media pengajaran semestinya diletakkan di kelas agar memudahkan dalam penggunaannya. Setelah itu papan tulis, kapur tulis, dan lain-lain, ukurannya disesuaikan, warnanya harus kontras, penempatannya memperhatikan estetika dan terjangkau oleh semua siswa.

Berdasarkan hasil observasi peneliti untuk perpustakaan di kelas masih menjadi kendala karena terbatas nya ruangan kelas tersebut. Sedangkan, pengunaan media pembelajaran hanya ada beberapa gambar yang di pajang atau ditinggal dikelas seperti gambar pahlawan atau contoh gambar yang berkaitan dengan mata pelajaran IPA selain itu untuk media lainnya menggunakan sepeaker atau laptop. Berikut hasil wawancara dengan Ibu Rohima selaku Wali kelas dan Waka Kesiswaan, sebagai berikut:

"untuk pembelajaran terkadang harus menggunakan media agar peserta didik lebih mengerti terhadap apa yang guru ajar kan. adapun media yang digunakan, yaitu menggunakan media yang sesuai dengan apa yang diajarkan, baik media gambar, alat yang dibuat sendiri, menggunakan handphone".

Berikut hasil wawancara dengan ibu Hotipah selaku Kepala Sekolah, sebagai berikut:

"ada beberapa alat pengajaran yang digunakan seperti gambar pahlawan. Gambar-gambar tersebut digantung sedemikian rupa sehingga selain dapat digunakan sebagai sumber belajar, juga dapat digunakan untuk menghias kelas. Sedangkan alat pengajar yang lain yang tidak dapat digantung, saya letakkan di lemari kelas agar tidak rusak".

Peneliti juga mewawancara Staf Tata Usaha Ibu Siti Sarah sebagai berikut:

"untuk perlengkapan kelas jika di lihat dari ukuran kelas nya, perlengkapan yang tersedia sudah cukup memadai 
dalam menunjang proses belajar. Sedangkan untuk sarananya sudah cukup baik tetapi belum dikategorikan lengkap".

Dari hasil observasi, wawancara dan dokumentasi ke empat narasumber dapat disimpulkan bahwa media pembelajaran yang digunakan itu tergantung pada materi yang di sampaikan misalnya, materinya cerita maka media nya bisa berupa laptop dan speaker. Ada beberapa alat pengajaran yang digunakan seperti gambar pahlawan. Gambar-gambar tersebut digantung sedemikian rupa sehingga dapat digunakan sebagai sumber belajar, juga dapat digunakan untuk menghias kelas. Hanya saja ada beberapa media pembelajaran belum bisa di katakan lengkap untuk menunjang proses belajar.

\section{Faktor Pendukung dan Penghambat Implementasi Manajemen Kelas}

Selanjutnya berkaitan dengan faktorfaktor dalam implementasi manajemen kelas di MI Quraniyah 8 Palembang, yakni berdasarkan hasil observasi, wawancara dan dokumentasi dengan guru-guru di MI Quraniah 8 Palembang, bahwasanya telah diketahui faktor yang menjadi penghambat dan pendukung dalam proses belajar mengajar. 1) Faktor penghambat Manajemen Kelas; Pada manajemen kelas ada beberapa faktor yang menjadi penghambat dalam proses berlangsungnya belajar mengajar yaitu faktor peserta didik, faktor gedung sarana dan prasarana, faktor fasilitas dan faktor keluarga. Faktor penghambat yang pertama berasal dari siswa itu sendiri. Murid merupakan unsur kelas yang memiliki perasaan kebersamaan merupakan kondisi yang penting dalam menciptakan kelas dinamis. Perasaan ini yang akan menumbuhkan rasa tanggung jawab terhadap kelasnya. Ketika murid masih bermain-main selama pelajaran berlangsung akan menjadi kendala atau penghambat manajemen kelas itu sendiri. Hal ini di ungkapkan oleh Ibu Rohima dan bapak hendri ketika ditanya mengenai hambatan yang terjadi pada siswa ketika pelajaran berlangsung. Ibu Rohima mengatakan :

"masalah di kelas itu pasti ada dan untuk masalah individu itu yang sering terjadi adalah siswa yang bicara dengan teman sebelah disaat pembelajaran berlangsung, atau siswa yang kurang aktif dalam proses belajar terkadang juga kurang nya kesadaran peserta didik dalam memenuhi tugas dan haknya sebagai anggota satu kelas dan pelanggaran tata tertib sekolah. begitu pun sama hal nya seperti yang di sampai kan oleh bapak hendri susanto beliau mengatakan bahwa kurangnya disiplin akan kesadaran peserta didik terhadap hak dan tanggung jawabnya dalam menjalankan tugas nya."

Faktor gedung dan sarana kelas juga masih mempunyai kendala seperti halnya yang dikatakan oleh ibu Hotipah selaku kepala sekolah :

"menuut ibu gedung itu harus sesuai dengan kapasitas siswanya, karena jika gedungnya berkapasitas kecil siswanya terlalu banyak maka akan mengganggu kenyamanan siswa pastinya ruangan akan lebih sempit dan panas. Lalu kebersihan gedung seperti ruangan kelas juga harus perlu diperhatikan karena kelas yang kotor itu bisa mengganggu kenyamanan siswa belajar.

Dari hasil penelitian observasi, wawancara, dan dokumentasi dapat dipahami 
Hikmah, Vol. 18, No. 2, Juli-Desember 2021， p-ISSN: 1829-8419 e-ISSN: 2720-9040

bahwa sekolah yang bersih dan indah merupakan faktor terpenting menjaga kualitas sekolah. Untuk fasilitas, pihak sekolah juga mempunyai kendala. Terkadang siswa sendirilah yang merusak fasilitasfasilitas yang Ada di dalam kelas. Hal ini menunjukan kurangnya rasa perhatian siswa terhadap fasilitas yang ada di dalam kelasnya. Dalam wawancaranya lebih lanjut pak Hendri mengatakan:

"kalau faktor penghambat itu biasanya dari siswa itu sendiri. Terkadang fasilitas itu banyak yang rusak karena siswa itu merasa tidak memiliki, tapi tetap kita mengingatkan sebagai guru agar menjaga fasilitas-fasilitas tersebut. Selain itu juga kurangnya alat media dan sumber belajar seperti alat peraga. Sehingga dapat membuat proses pembelajaran sedikit terhambat."

Dapat disimpulkan hasil wawancara ke beberapa guru di MI Quraniah 8 Palembang yaitu faktor itu sendiri juga berasal dari siswa. Masih ada siswa yang bermain-main pada saat pelajaran berlangsung. Selain itu juga, siswa kurang perhatian terhadap fasilitas-fasilitas yang ada di dalam kelasnya masing-masing. Banyak fasilitas yang rusak karena siswa kurang merasa memiliki. Selain itu gedung dan sarana kelas juga masih menjadi kendala atau faktor penghambat manajemen kelas di MI Quraniah 8 Palembang. 2) Faktor pendukung; Guru adalah salah satu faktor pendukung manajemen kelas. Faktor yang dapat mempengaruhi pada hasil belajar siswa, salah satunya faktor dari guru itu sendiri. Karena, apabila guru hanya mengajar saja tanpa mengetahui bagaimana kondisi fisik dan psikis siswa tidak akan pernah berjalan efektif. Maka dari itu, untuk mengantisipasi dan menghindari hal demikian kepala sekolah sebagai manajer, supervisor, administrator, dan fasilitator mempunyai tanggung-jawab dalam memberi pengarahan/ pembinaan dan bimbingan kepada Bapak/ Ibu guru, baik secara langsung maupun tidak langsung. Seperti yang di sampaikan oleh ibu Rohima :

"menurut ibu guru itu sangat berperan penting dalam sebuah kelas karena itu bidang guru harus sesuai dengan apa yang di ajarkan selain itu juga guru harus aktif dan berjiwa bebas serta kreatif dalam mengarahkan perkembangan anak didiknya."

Apabila guru melakukan kesalahan dalam Pembelajaran, akan diberi peringatan khusus demi perbaikan dalam pengajaran dan pembelajaran. Guru juga diikut-sertakan dalam program-program pendidikan, seperti seminar pendidikan, penataran guru, workshop, dll. Untuk menunjang dan menjadikan mereka sebagai guru yang profesional. Ditambah lagi dengan latar belakang pendidikan dan ijazah terakhir sebagai sarjana. Maka, para guru yang ada di MI Quraniah 8 Palembang. sangat berkompeten sesuai dengan bidangnya masing-masing. Selain itu faktor pendukung yang lain juga yang mendorong kelancaran menejemen kelas itu adalah faktor kurikulum. Dengan adanya kurikulum maka pembelajaran dapat diselenggarakan secara berencana. Seperti yang dikatakan oleh pak Hendri:

"kurikulum itu amat berkaitan ya dengan manajemen kelas Karena apa, tanpa kurikulum maka pembelajaran ini tidak tahu arahnya akan kemana jadi menurut saya penting sekali kurikulum menjadi pedoman saat proses mengajar berlangsung, untuk 
saat ini di MI Quraniah 8 Palembang itu sendiri, menggunakan kurikulum 2013 yang sudah berjalan 3 tahun terakhir."

Selain faktor kurikulum hal yang mendukung di dalam manajemen kelas yaitu faktor dinamika kelas yang mana lingkungan fisik tempat belajar mempunyai pengaruh penting terhadap hasil pembelajaran. Berdasarkan hasil observasi dinamika kelas atau lingkungan kelas sangat berpengaruh penting di dalam majemen kelas seperti contoh penataan kelas yang tidak membosankan tetapi lebih bervariasi sehingga membuat ruangan kelas menjadi menarik dan tertata baik, yang mengakibatkan siswa menjadi lebih termotivasi dan dengan monitoring yang dilakukan terhadap siswa serta komunikasi yang dilakukan secara terus menerus antara guru dengan Wali kelas dapat mengakibatkan terciptanya kelas yang kondusif dan menyenangkan. Dengan demikian keberhasilan manajemen kelas akan mudah tercapai apabila siswa itu sendiri senang terhadap pelajaran yang diajar oleh guru mata pelajaran yang bersangkutan. Selain guru kurikulum dan dinamika kelas juga adalah faktor pendorong keberhasilan manajemen kelas.

\section{SIMPULAN}

Berdasarkan penjelasan di atas maka dapat disimpulkan berkaitan dengan implementasi manajemen kelas di MI Quraniah 8 Palembang. Dalam pelaksanaan manajemen Kelas yang dilakukan oleh guruguru sudah berjalan dengan baik namun kurang maksimal. Adapun Pengaturan fasilitas yang terdiri dari pengaturan ruang belajar, pengaturan tempat duduk, pengaturan ventilasi udara, pengaturan cahaya dan pengaturan alat pembelajaran sudah terealisasi dan terlaksana. tetapi perlu adanya perbaikan secara terus menerus. Faktor penghambat dalam pelaksanaan manajemen kelas yakni faktor yang utamanya peserta didik, kurangnya kesadaran peserta didik dalam memenuhi hak dan tanggung jawab dalam menjalankan tugasnya, lalu kecerdasan siswa yang beragam sehingga dapat menghambat proses pembelajaran. faktor fasilitas, gedung dan sarana kelas yaitu kurangnya jumlah ruangan kelas dibandingkan dengan banyaknya jumlah kelas dan kurangnya media dan sumber belajar alat peraga. Sedangkan, faktor pendukungnya yaitu pertama faktor guru, guru memiliki peran yang penting oleh sebab itu dalam sebuah kelas karena guru harus aktif dan berjiwa bebas serta kreatif dalam mengarahkan perkembangan anak didiknya. Faktor kurikulum tanpa adanya kurikulum pembelajaran dikelas tidak akan berjalan sebagaimana mestinya dan yang terakhir faktor dinamika kelas yang mana lingkungan fisik tempat belajar mempunyai pengaruh penting terhadap hasil pembelajaran.

\section{DAFTAR PUSTAKA}

Almasri, M. N. (2017). Manajemen Sumber Daya Manusia: Imlementasi dalam Pendidikan Islam. Kutubkhanah, 19(2), 133-151. http://ejournal.uinsuska.ac.id/index.php/Kutubkhanah/article/ view/2547

Anwar, A., Daud, M., Abubakar, A., Zainuddin, Z., \& Fonna, F. (2020). Analisis Pengaruh Gaya Mengajar Guru Terhadap Prestasi Belajar Siswa. Jurnal 
Hikmah, Vol. 18, No. 2, Juli-Desember 2021， p-ISSN: 1829-8419 e-ISSN: 2720-9040

Serambi Ilmu, 21(1), 64-85. https://doi.org/10.32672/si.v21i1.1883

Arianti, A. (2019). Urgensi Lingkungan Belajar Yang Kondusif Dalam Mendorong Siswa Belajar Aktif. Didaktika: Jurnal Kependidikan, 11(1), 41-62. http://dx.doi.org/10.30863/didaktika.v11i1. 161

Asmara, Y., \& Nindianti, D. S. (2019). Urgensi Manajemen Kelas untuk Mencapai Tujuan Pembelajaran. Sindang: Jurnal Pendidikan Sejarah Dan Kajian Sejarah, 1(1), 12-24. https://doi.org/10.31540/sdg.v1i1.192

Aulia, R., \& Sontani, U. T. (2018). Pengelolaan kelas sebagai determinan terhadap hasil belajar. Jurnal Pendidikan Manajemen Perkantoran (JPManper), 3(2), 149-157. https://doi.org/10.17509/jpm.v3i2.11759

Bani, S. (2016). Tantangan Lembaga Pendidikan di Tengah Persaingan Global. Jurnal Inspiratif Pendidikan, 5(2), 447458. https://doi.org/10.24252/ip.v5i2.3577

Erwinsyah, A. (2017). Manajemen kelas dalam meningkatkan efektifitas proses belajar mengajar. Tadbir: Jurnal Manajemen Pendidikan Islam, 5(2), 87-105. https://www.journal.iaingorontalo.ac.id/inde x.php/tjmpi/article/view/392

Faruqi, D. (2018). Upaya meningkatkan kemampuan belajar siswa melalui pengelolaan kelas. Evaluasi: Jurnal Manajemen Pendidikan Islam, 2(1), 294-310. http://dx.doi.org/10.32478/evaluasi.v2i1.80

Fauziyah, N. (2021). Pengelolaan Kelas Dalam Pembelajaran Aqidah Akhlaq di Era Pendemi Covid-19 Pada Siswa Kelas V di Mi Darul Ulum Desa Benem Kecamatan Duduksampeyan Kabupaten Gresik [Universitas Muhammadiyah Gresik]. http://eprints.umg.ac.id/5110/

Firdaus, R. (2016). Pengaruh Penataan Ruang Kelas Terhadap Hasil Belajar Siswa Kelas V (Study eksperimen di SDN 4 Kuripan Utara) tahun 2016 (pp.
1-5). Universitas Mataram. http://eprints.unram.ac.id/9947/

Gafur, A., \& Mustafida, F. (2019). Strategi Pengelolaan Kelas dalam Menciptakan Suasana Belajar Yang Kondusif Di Sd/Mi. Elementeris: Jurnal Ilmiah Pendidikan Dasar Islam, 1(2), 38-44. http://dx.doi.org/10.33474/elementeris.v $1 \mathrm{i} 2.4991$

Huda, M. (2015). Peran Pendidikan Islam Terhadap Perubahan Sosial. Edukasia: Jurnal Penelitian Pendidikan Islam, 10(1), 165-188. http://dx.doi.org/10.21043/edukasia.v10i1.790

Isnanto, I., Pomalingo, S., \& Harun, M. N. (2020). Strategi pengelolaan kelas di sekolah dasar. Jurnal Pendidikan Glasser, 4(1), 7-24. https://doi.org/10.32529/glasser.v4i1.392

Moloeng, L. J. (2018). Metodologi Penelitian Kualitatif Remaja Rosdakarya. Inter Komunika, Stikom InterStudi.

Mutiaramses, M., Neviyarni, S., \& Murni, I. (2021). Peran Guru dalam Pengelolaan Kelas Terhadap Hasil Belajar Siswa Sekolah Dasar. Pendas: Jurnal Ilmiah Pendidikan Dasar, 6(1), 43-48. http://dx.doi.org/10.23969/jp.v6i1.4050

Nurmala, S. R. (2019). Pengelolaan Kelas dalam Pembelajaran Tematik pada Peserta Didik Kelas II MI Pembangunan UIN Jakarta [FITK UIN Syarif Hidayatullah Jakarta]. https://repository.uinjkt.ac.id/dspace/ha ndle/123456789/39854

Rosidah, S. (2020). Pengaruh Pengelolaan Kelas terhadap Prestasi Belajar Siswa di MI AlKaromah. Mimbar Kampus: Jurnal Pendidikan Dan Agama Islam, 19(1), 5064. https://doi.org/10.47467/mk.v19i1.426

Sa'diyah, M. A. S. H. (2017). Model Pengelolaan Kelas dalam Pembelajaran PAI di SD Riyadlul Arkham Tembong Plintahan Pandaan. Jurnal Al-Murabbi, 2(2), 291-310. https://jurnal.yudharta.ac.id/v2/index.php/pai /article/view/608 
Sumar, W. T. (2020). Pengelolaan Kelas dalam Meningkatkan Motivasi Belajar Siswa. Jambura Journal of Educational Management, $\quad 1(1), \quad 49-59$. https://doi.org/10.37411/jjem.v1i1.105

Wajdi, F. (2021). Manajemen Perkembangan Siswa SD Melalui Peran Guru Dan Orang Tua Pada Masa Pandemi. JAMP: Jurnal Administrasi Dan Manajemen Pendidikan, 4(1), 41-50. http://dx.doi.org/10.17977/um027v4i12 $021 \mathrm{p} 41$ 